\title{
A multivariate climate index for the western coast of Colombia
}

\section{E. Rodríguez-Rubio}

Dirección General Marítima, Centro de Investigaciones Oceanográficas e Hidrográficas del Pacífico, Área de Oceanografía Operacional, Grupo de Estudios Oceanográficos del Fenómeno El Niño, Capitanía de Puerto, San Andrés de Tumaco, Nariño, Colombia now at: Instituto Colombiano del Petróleo - ICP, Piedecuesta, Santander, Colombia

Correspondence to: E. Rodríguez-Rubio (erodriguezrubio@yahoo.com.ar)

Received: 18 May 2011 - Revised: 15 September 2011 - Accepted: 1 October 2012 - Published: 2 April 2013

\begin{abstract}
Indices of the interannual and interdecadal variability at Tumaco Island $\left(2^{\circ} \mathrm{N} ; 79^{\circ} \mathrm{W}\right.$; Colombia), based on time series of sea surface temperature (SST), air temperature (AT) and precipitation $(P)$ from a coastal station, are presented regarding the period 1960-2010. These indices are derived from the first two EOF (empirical orthogonal function) modes of the normalized time series, which grasp $84 \%$ of the explained variance. The first EOF represents the interannual variability closely correlated with the ENSO-related SST variability of region Niño $1+2(r=0.74 ; \mathrm{lag}=1)$, Niño $3(r=0.71 ; \mathrm{lag}=1)$, and the well-known period band 28 yr. Furthermore, the first EOF also accounts for the extreme warm events in the eastern equatorial Pacific due to them being well correlated with the E index $(r=0.70)$. The second EOF represents a much longer variability dominated by the ENSO-like mode or Pacific Decadal Oscillation (PDO), represented by two interdecadal modes (8-16 yr and 20-30 yr), and may account also with moderate warm events and cool events, being more sensitive to cool events.
\end{abstract}

\section{Introduction}

The Colombian Pacific ocean is located in the Panama Bight and is described as part of the eastern tropical Pacific Ocean delimited by the Isthmus of Panama $\left(9^{\circ} \mathrm{N}\right)$ and Puntilla Santa Elena $\left(2^{\circ} \mathrm{S}\right)$ (Fig. 1). It extends westward from the coasts of Panama, Colombia and Ecuador to about $81^{\circ} \mathrm{W}$, and is subject to pronounced seasonal variations in oceanic conditions related to changes in the position of the Intertropical Convergence Zone (ITCZ) and the development of the low wind jet event usually referred to as the Panama Jet (Chelton et al., 2001; Rodríguez-Rubio et al., 2003; Kessler, 2006). At the same time, the region is also subject to strong interannual forcing associated with the El Niño Southern Oscillation (e.g. Fiedler et al., 1992; Poveda and Mesa, 1997; Wang and Fiedler, 2006).

The eastern tropical Pacific is a region affected mainly by the El Niño Southern Oscillation (ENSO), a global air-sea interaction phenomenon with interannual time scales (typically in the $1.5-8 \mathrm{yr}$ band) that is the largest source of variability in the tropical region (e.g. Rasmusson and Carpenter, 1982; Wang and Fiedler, 2006; Mestas-Nuñez and Miller, 2006).

For longer time periods, several studies have documented decadal-to-interdecadal variability in the Pacific Ocean, mainly in the tropics and North Pacific (e.g. Nitta and Yamada, 1989; Trenberth, 1990; Mestas-Nuñez and Miller, 2006). Nevertheless, South America has a few studies with long coastal in situ time series of atmospheric and oceanic variables to study the interannual and interdecadal variability (Montecinos et al., 2003).

Here, coastal monthly time series of sea surface temperature (SST), air temperature (AT) and precipitation $(P)$ from a coastal station located on Tumaco Island in the Colombian Pacific for the period 1960-2010 were used and analyzed using statistical methods focusing on the interannual to interdecadal variability.

\section{Data and methodology}

Sea surface temperatures (SST), air temperature (AT) and precipitation $(P)$ monthly time series were obtained from coastal station of the "Centro de Investigaciones Oceanográficas e Hidrográficas del Pacifico-CCCP”, located 


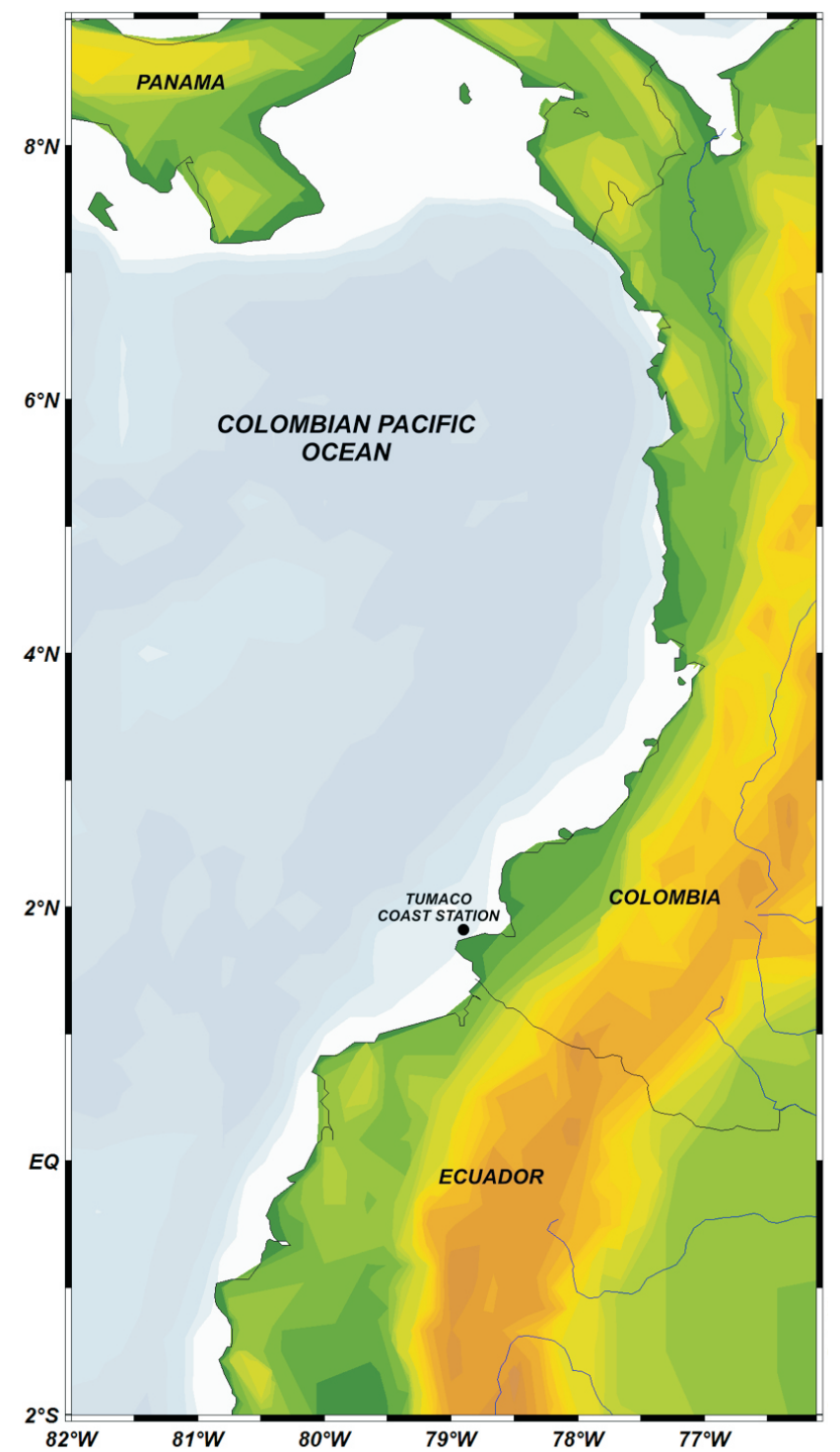

Fig. 1. Map of the study area and location of Tumaco coastal station.

on Tumaco Island $\left(01^{\circ} 49^{\prime} 12^{\prime \prime} \mathrm{N} ; 78^{\circ} 43^{\prime} 43^{\prime \prime} \mathrm{W}\right)$ in the Colombian Pacific Ocean; data from 1960 to 2010 (Fig. 1). Several statistical techniques were used to guarantee the homogeneity and continuity of the time series, including standard normal homogeneity test (e.g. Thom, 1966; Brockwell and Davis, 1991), seasonal decomposition (Wei, 2006) and geospatial models (Barón-Leguizamón, 2003). The latter technique was used to fill gaps in the precipitation and air temperature time series.

The mean climatology calculated over 1971-2000 was removed to define the anomalies. The Monthly Niño $1+2(0$ $\left.10^{\circ} \mathrm{S}\right)\left(90-80^{\circ} \mathrm{W}\right)$, Niño $3\left(5^{\circ} \mathrm{N}-5^{\circ} \mathrm{S}\right)\left(150-90^{\circ} \mathrm{W}\right)$, Niño $4\left(5^{\circ} \mathrm{N}-5^{\circ} \mathrm{S}\right)\left(160^{\circ} \mathrm{E}-150^{\circ} \mathrm{W}\right)$, Niño $3.4\left(5^{\circ} \mathrm{N}-5^{\circ} \mathrm{S}\right)(170$ $120^{\circ} \mathrm{W}$ ) and decadal Pacific Decadal Oscillation index was taken from the Joint Institute for the Study of the Atmosphere and Ocean (JISAO, http://www.jisao.washington.edu/
Table 1. Cross-correlation of the EOFs with Niño region SST anomalies (indices), $\mathrm{E}$ and $\mathrm{C}$ indices.

\begin{tabular}{lll}
\hline Indices & $\begin{array}{l}\text { Cross-correlation } \\
(\text { EOF1) }\end{array}$ & $\begin{array}{l}\text { Cross-correlation } \\
(\text { EOF2) }\end{array}$ \\
\hline SST Niño 1+2 & $0.74(\operatorname{lag} 1)$ & $0.32(\operatorname{lag} 1)$ \\
SST Niño 3 & $0.71(\operatorname{lag} 1)$ & $0.42(\operatorname{lag} 1)$ \\
SST Niño 3.4 & $0.62(\operatorname{lag} 2)$ & $0.43(\operatorname{lag} 0)$ \\
SST Niño 4 & $0.47(\operatorname{lag} 2)$ & $0.41(\operatorname{lag} 0)$ \\
E & $0.70(\operatorname{lag} 1)$ & $0.23(\operatorname{lag} 1)$ \\
C & $0.30(\operatorname{lag} 2)$ & $0.42(\operatorname{lag} 0)$ \\
\hline
\end{tabular}

data_sets/). The uncorrelated indices (E and C) proposed by Takahashi et al. (2011), which respectively account for the extreme warm events in the eastern and cold/moderate warm events in the central equatorial Pacific, were analyzed against the first two EOF coefficients from the Tumaco index.

Two statistical methods were used to characterize the interannual and decadal variability. First, the empirical orthogonal function (EOF) analysis was used to isolate the most important modes of variability in the simultaneous and standardized matrix of SST, AT and $P$ anomalies data (e.g. Emery and Thomson, 2001; Von Storch and Zwiers, 2001). Second, the wavelet analysis (Torrence and Compo, 1998; Emery and Thomson, 2001; Weng and Lau, 1994) was used to separate the existing oscillations within the original signal (see Garcés-Vargas et al., 2005 for an application). In this study the continuous Morlet wavelet transformation was used and applied onto the time series obtained from the EOF analysis. The advantage of using the Morlet wavelet is its complex nature that is able to detect both time-dependent amplitude and phase for different frequencies exhibited in the time series (Lau and Weng, 1995). The wavelet analysis in this study uses the chi-squared distribution to find the $95 \%$ confidence level, assuming a background Fourier red noise spectrum modelled by a univarite lag- 1 autoregressive process (AR1). The confidence level is applied to the contours and the confidence line for the global wavelet spectrum (Torrence and Compo, 1998).

\section{Results}

The first two EOF coefficients (EOF1, EOF2) of monthly sea-air variables from Tumaco are shown in Fig. 2. They represent $50 \%$ and $34 \%$ of the total variance, respectively. As can be seen from Table 1, The EOF1 is well correlated with El Niño $1+2(=0.74$; lag $=1 ; p<0.05)$ and Niño 3 region $(r=0.71 ; \operatorname{lag}=1 ; p<0.05)$. These interannual modes can be interpreted as the ENSO signal in the air-sea variables in Tumaco and show the ENSO history between 1961 to 2010 in the Colombian Pacific Ocean. Furthermore, the cross-correlation between EOF1 and E index (that accounts 

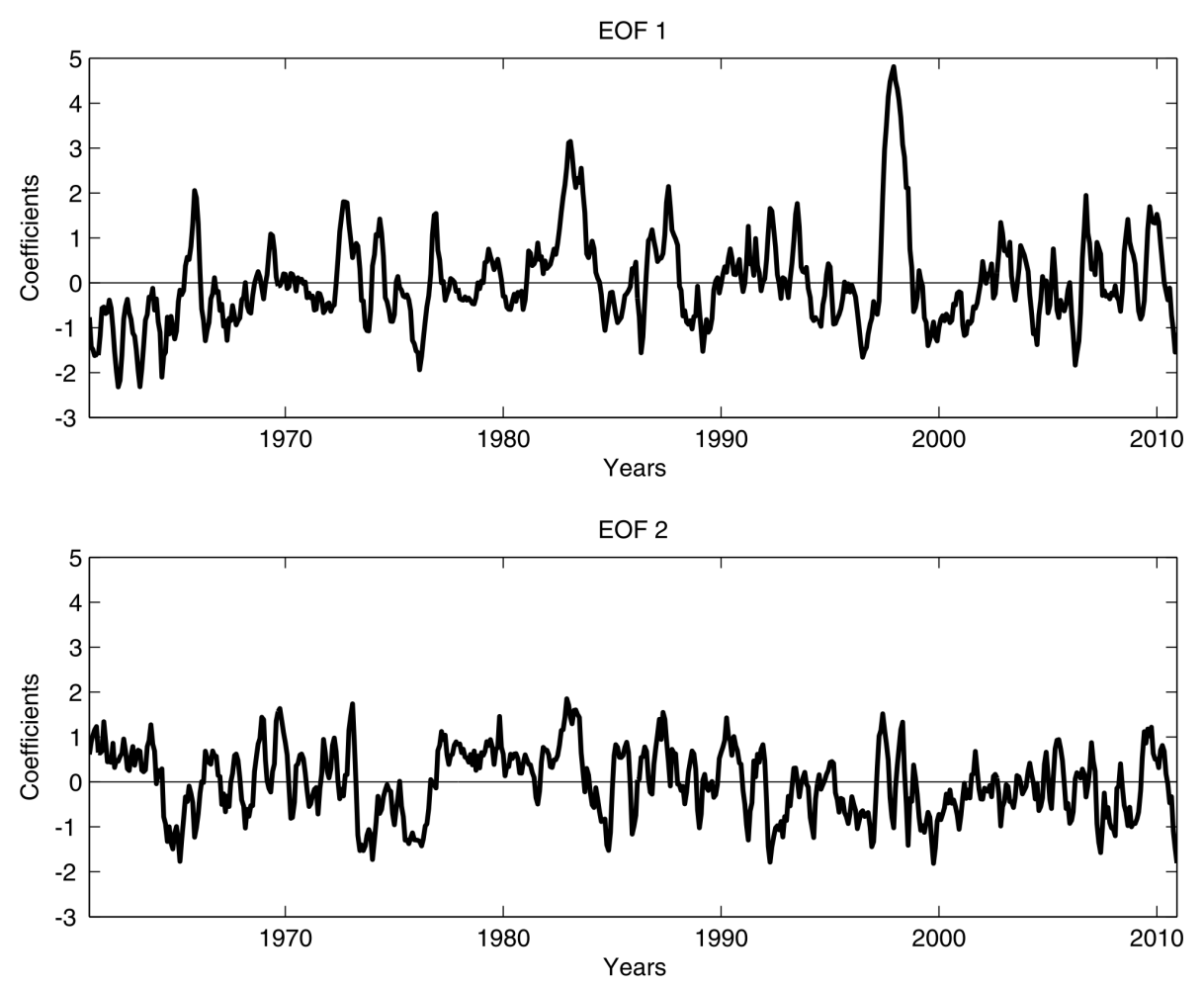

Fig. 2. Time series of EOF1 (top) and EOF2 (bottom) of the sea-air variables of Tumaco, Colombia.

for extreme warm events in the eastern equatorial Pacific) was well correlated $(r=0.70 ; \operatorname{lag}=1 ; p<0.05)$.

The wavelet analysis applied to EOF1 shows two high energetic interannual modes with dominant frequencies around periods 2.3 and 4.9 yr at a $95 \%$ confidence level (see Fig. 3a). These two frequencies may be identified with those arising from quasi-biennial oscillation (QBO) and the El Niño Southern Oscillation (ENSO) (Barnett, 1991; Neelin et al., 1998; Lau and Weng, 1995) and reported regarding the Colombian Pacific by Poveda and Mesa (1997), Waylen and Poveda (2002) and Díaz-Ochoa et al. (2004). In Fig. 3b, most of the power is concentrated within the ENSO band of 2-8 yr, although there is appreciable power at longer periods, both signal significant at a $95 \%$ confidence level. Scale-averaged wavelet power over the 2-8 yr band for the EOF1 (Fig. 3d) shows a distinct period between 1961 and 1977 when ENSO variance was low, and 1981 to 2003 period when ENSO variance was high, decreasing from 2003 to 2010 . The change in the variance can be interpreted like a climate regime shift in the EOF1 time series (Fig. 3d, red bars). The regime of 1960-1977 shows a low and quasi-stable variance period. The next regime 1977-1989 shows a sustainable variance increase with a maximum related to El Niño 1982-1983. The 1989-2003 period shows an important variance increase, with the peak at 1997-1998 related to the El Niño. After of 2003 the variance decreases until 2010 (Fig. 3d). The variance change found in the Tumaco EOF air-sea time series resembles the changes in the interdecadal timescale in the time series of physical and biological variables reported by Hare and Mantua (2000) and Mantua and Hare (2002) for the Pacific Ocean, and Mestas-Nuñez and Miller (2006) for the Eastern Tropical Pacific.

Cross-correlation analysis was made between EOF2 and all SST ENOS indices, showing poor correlation $(r<0.50$, Table 1) in all cases and indicating that there is another factor of variability in the signal different of the well-known ENSO mode. On the other hand, cross-correlation between EOF2 and $\mathrm{C}$ index (which accounts for moderate warm events and cool events) does not exceed $0.42(p<0.05)$; nevertheless, a cross-correlation when $C>0.5(r=0.34$; lag $=-1$; $p<0.05)$ and $C<-0.5(r=0.64 ;$ lag $=0 ; p<0.05)$ shows that EOF2 from the Tumaco index is more sensitive to cool events. The wavelet analysis was applied to EOF2 (Fig. 4), showing that most of the power is concentrated within the interdecadal band of 8-16 yr; the signal of the ENSO period ( $2-8$ yr) is still observed but less energetic. Scale-averaged wavelet power over the 6-20 yr band for the EOF2 shows a distinct period between 1961 and 1976 when decadal variance was high, and the 1977 to 2010 period when the signal shows a tendency to decrease with low variances. This low-frequency variability appears to be dominated by decadal periods $8-16 \mathrm{yr}$ and $20-30 \mathrm{yr}$, related to the SST mode in the tropical Pacific referred to as the ENSO-like 
a) Tumaco Index Wavelet Power Spectrum

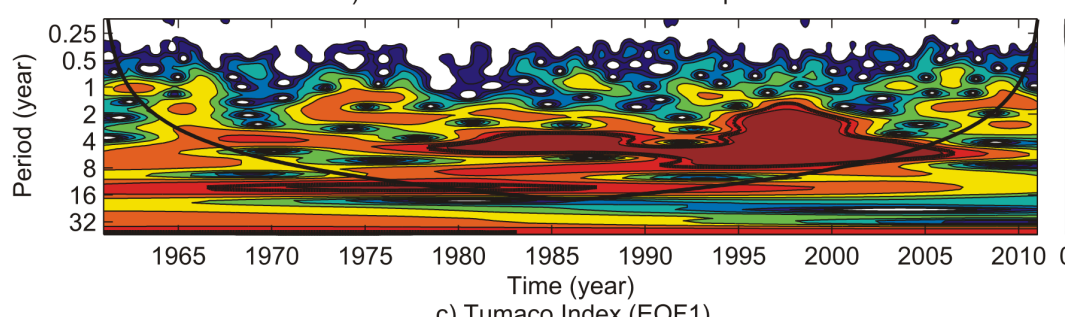

c) Tumaco Index (EOF1)

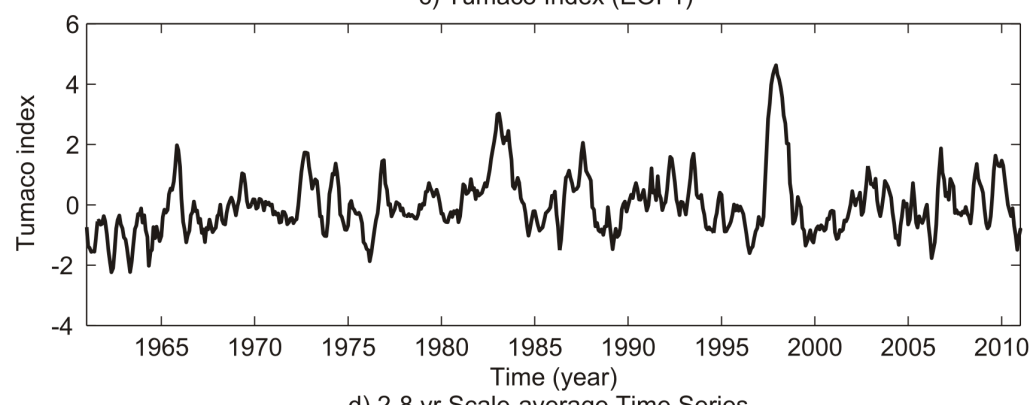

d) 2-8 yr Scale-average Time Series

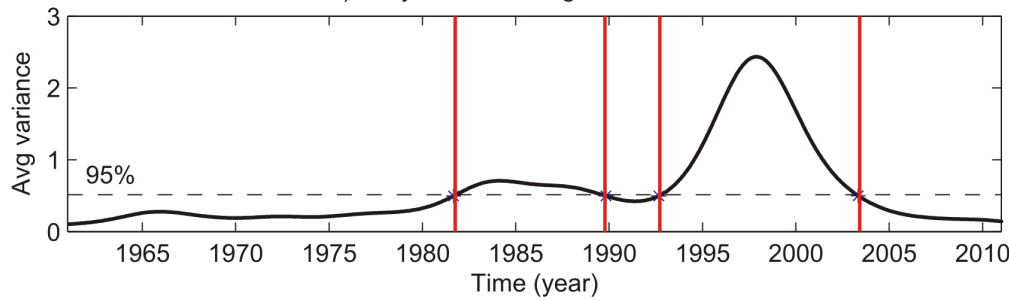

b) Global Wavelet Spectrum
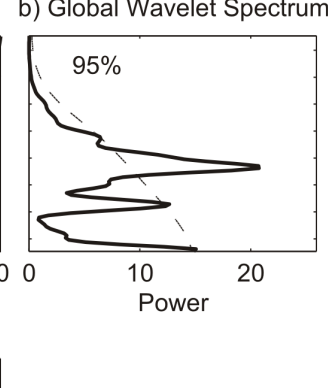


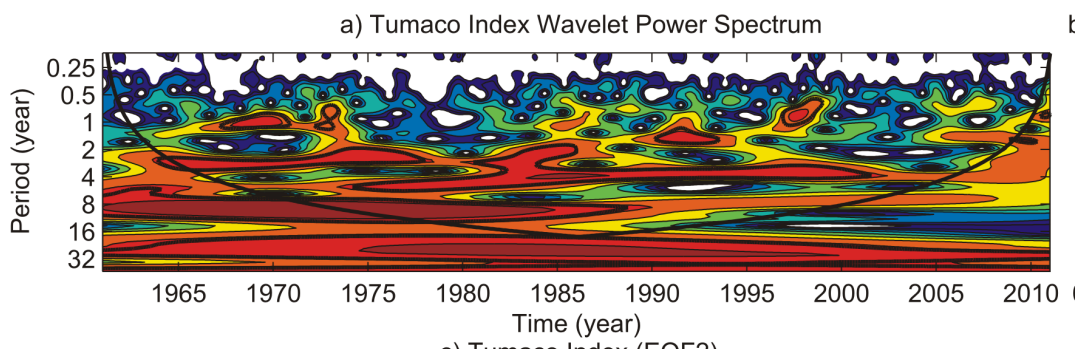

b) Global Wavelet Spectrum
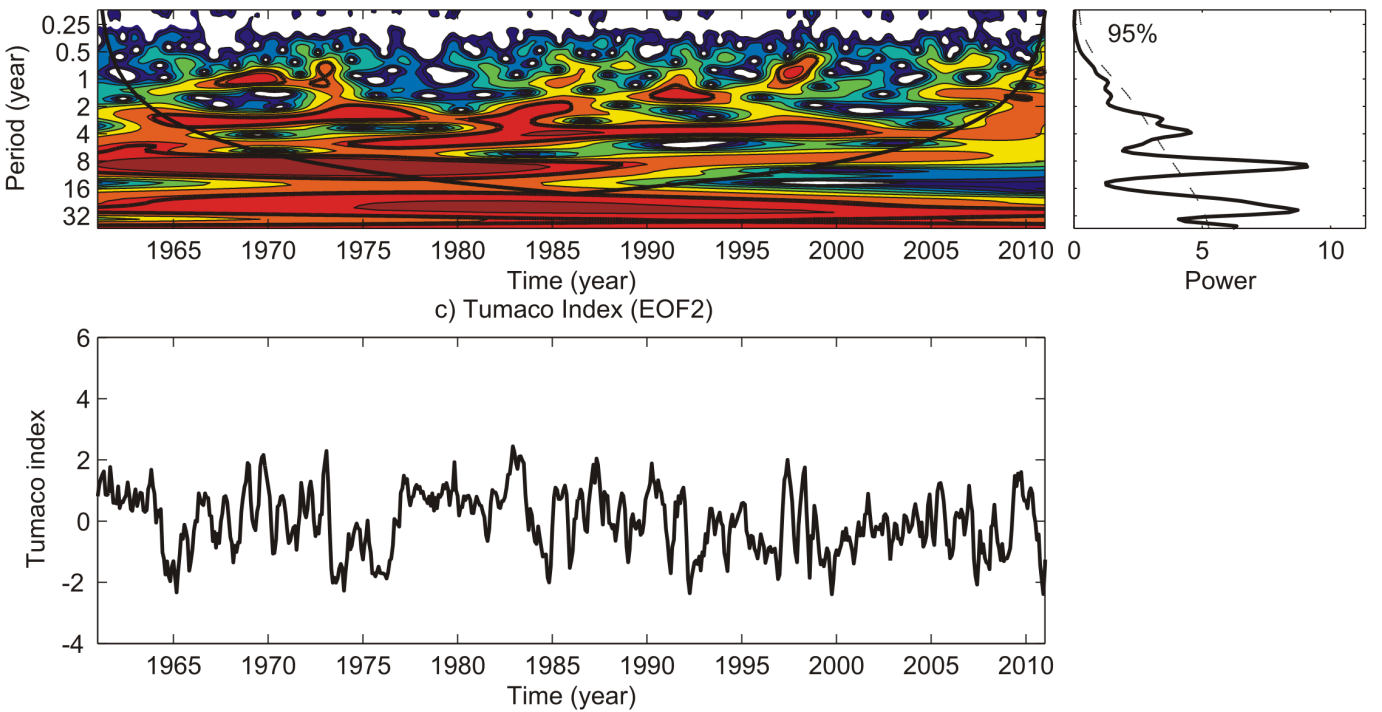

d) 6-20 yr Scale-average Time Series

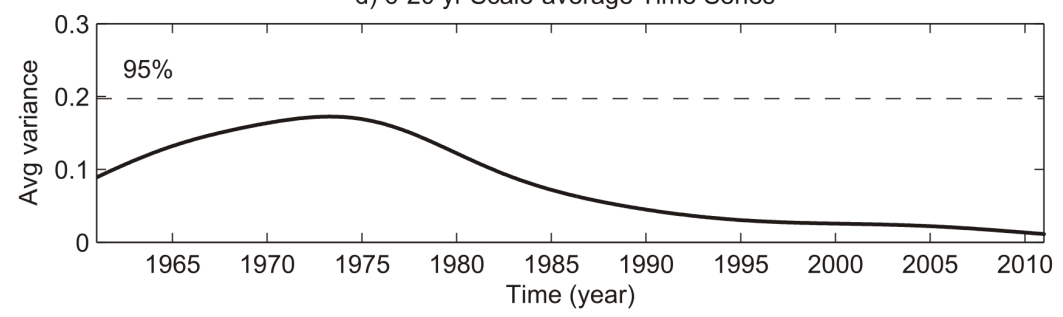

Fig. 4. Morlet wavelet power spectrum of EOF2 (a), global wavelet spectrum (b), time series of EOF2 (c) and 6-20 yr scale-averaged power wavelet of the EOF2 time series of Tumaco sea-air variables (d).

and cool events) and the Tumaco index does not exceed 0.42 (with EOF2), which is significant $(P<0.05)$. It suggests that the Tumaco index may account to some extent for the teleconnection pattern associated to Central Pacific El Nino/La Niña, and also be more sensitive to cool events due to best correlation (0.64) with the cool signal $(C<-0.5)$ of the $\mathrm{C}$ index.

On the other hand, the low frequency signal in the Tumaco time series shows that interdecadal air-sea variability in the Colombian Pacific Ocean is related to North Pacific interdecadal oscillation or ENSO-like modes. These results confirm the basin-wide character of this long-term variability suggested by other works with other coastal time series located in the southern part of South America.

Acknowledgements. The author thanks the Oceanographic and Hydrographic Research Centre of the Pacific (CCCP) and the "Estudio de los procesos que afectan la termoclina y la temperatura superficial del mar en el borde costero del Pacífico colombiano, orientado al desarrollo de un índice local operacional del ENOS" research project supported by General Maritime Directorate (DIMAR).

\section{References}

An, S.-I. and Wang, B: Interdecadal change of the structure of the ENSO mode and its impact on the ENSO frequency, J. Climate., 13, 2044-2055, 2000.

Barlow, M., Nigam, S., and Berbery, E. H.: ENSO, Pacific decadal variability, and U.S. summertime precipitation, drought, and streamflow, J. Climate, 14, 2105-2128, 2001.

Barnett, T. P.: The interaction of multiple time scales in the tropical climate system, J. Climate., 4, 269-285, 1991.

Barón-Leguizamón, A.: Modelos geoespaciales de la distribución de las variables climatológicas en el territorio colombiano, Meteorología Colombiana, 7, 81-89, 2003.

Brockwell, M. J. and Davis, R. A.: Time Series: Theory and Methods, Springer Verlag, New York, 1991.

Chelton, D. B., Esbensen, S. K., Schlax, M. G., Thum, N., Freilich, M. H., Wentz, F. J., Gentemann, C. L., McPhaden, M. J., and Schopf, P. S.: Observations of coupling between surface wind stress and sea surface temperature in the Eastern Tropical Pacific, J. Climate, 14, 1479-1498, 2001.

Díaz-Ochoa, J. A., Rodríguez-Rubio, E., and Alvarez-León, R.: Oscilaciones quasi-bienales de un índice del reclutamiento del camarón Litopenaeus occidentalis con relación a la variabilidad climática del Pacífico Oriental Tropical, in: Contribuciones al Estudio de los Crustáceos del Pacífico Este, edited by: Hendrickx, M. E., Instituto de Ciencias del Mar y Limnología UNAM, 
Mazatlan, Mexico, 3, 17-29, 2004.

Emery, W. J. and Thompson, R. E.: Data analysis methods in physical oceanography, 2nd Edn., Elsevier, Amsterdam, The Netherlands, 2001

Fiedler, P. C., Chavez, F. P., Behringer, D. W., and Reilly, S. B.: Physical and biological effects of Los Niños in the eastern tropical Pacific, 1986-1989, Deep-Sea Res., 39, 199-219, 1992.

Garcés-Vargas, J., Schneider, W., Abarca del Río, R., Martínez, R., and Zambrano, E.: Inter-annual variability in the thermal structure of an oceanic time series station off Ecuador (1990-2003) associated with El Niño events, Deep-Sea Res. Pt. I, 52, 17891805, 2005.

Hare, S. R. and Mantua, N. J.: Empirical evidence for North Pacific regime shifts in 1977 and 1989, Prog. Oceanogr., 47, 103-145, doi:10.1016/S0079-6611(00)00033-1, 2000.

Kessler, W. S.: The circulation of the eastern tropical Pacific: A review, Prog. Oceanogr., 69, 181-217, 2006.

Lau, K. M. and Weng, H. Y.: Climate signal detection using wavelet transform: How to make a time series sing, B. Am. Meteor. Soc., 76, 2391-2402, 1995.

Mantua, N. J. and Hare, S. R.: The Pacific decadal oscillation, J. Oceanogr., 58, 35-44, 2002.

Mestas-Nuñez, A. M. and Enfield, D. B.: Rotated global modes of Non-ENSO sea surface temperature variability, J. Climate., 12, 2734-2746, 1999.

Mestas-Nuñez, A. M. and Miller, A.: Interdecadal variability and climate change in the eastern tropical Pacific: A review, Prog. Oceanogr., 69, 267-284, 2006.

Montecinos, A., Purca, S., and Pizarro, O.: Interannual-tointerdecadal sea surface temperature variability along the western coast of South America, Geophys. Res. Lett., 30, 1570, doi:10.1029/2003GL017345, 2003.

Neelin, J. D., Battisti, D. S., Hirst, A. C., Jin, F. F., Wakata, Y., Yamagata, T., and Zebiak, S.: ENSO Theory, J. Geophys. Res., 103, 261-290, 1998.

Nitta, T. and Yamada, S.: Recent warming of tropical sea surface temperature and its relationship to the Northern Hemisphere circulation, J. Meteor. Soc. Jpn., 67, 375-382, 1989.
Poveda, G. and Mesa, O. J.: Feedbacks between hydrological processes in tropical South America and large-scale oceanatmospheric phenomena, J. Climate, 10, 2690-2702, 1997.

Rasmusson, E. M. and Carpenter, T. H.: Variations in tropical sea surface temperature and surface wind fields associated with the Southern Oscillation/El Niño, Mon. Weather Rev., 110, 354-384, 1982.

Rodríguez-Rubio, E., Schneider, W., and Abarca del Río, R.: On the seasonal circulation within the Panama Bight derived from satellite observations of wind, altimetry and sea surface temperature, Geophys. Res. Lett., 30, 1410, doi:10.1029/2002GL016794, 2003.

Takahashi, K., Montecinos, A., Goubanova, K., and Dewitte, B.: ENSO regimes: Reinterpreting the canonical and Modoki El Niño, Geophys. Res. Lett., 38, L10704, doi:10.1029/2011GL047364, 2011.

Thom, H. C.: Some methods of climatological Análisis, Technical note, No. 81, World Meteorological Organization, 1966.

Torrence, C. and Compo, G. P.: A Practical Guide to Wavelet Analysis, B. Am. Meteor. Soc., 79, 61-78, 1998.

Trenberth, K. E.: Recent observed interdecadal climate changes in the Northern Hemisphere, B. Am. Meteor. Soc., 71, 988-993, 1990.

Von Storch, H. and Zwiers, F. W.: Statistical analysis in climate research, Cambridge University Press, Cambridge, United Kingdom, 2001.

Wang, C. and Fiedler, P. C.: ENSO variability in the eastern tropical Pacific: a review, Prog. Oceanogr., 69, 239-266, 2006.

Waylen, P. and Poveda, G.: El Niño-Southern Oscillation and aspects of western South American hydro-climatology, Hydrol. Process., 16, 1247-1260, 2002.

Wei, W. S.: Time Series Análisis, Univariate and Multivariate Methods, 2nd edition, Pearson Addison Wesley, Boston, 2006.

Weng, H.-Y. and Lau, K.-M.: Wavelet, period-doubling and time frequency localization with application organization of convection over the tropical western Pacific, J. Atmos. Sci., 51, 2523 2541, 1994. 